\title{
Cupredoxin domain of particulate methane monooxygenase (pMMO) gene expression in recombinant Escherichia coli
}

\author{
Tira Siti Nur Afiah ${ }^{1}$, Suharsono $^{2}$, Iman Rusmana ${ }^{3^{\star}}$ \\ ${ }^{1}$ Postgraduate School, Bogor Agricultural University, Darmaga Campus, Bogor 16680, Indonesia. \\ ${ }^{2,3}$ Department of Biology, Bogor Agricultural University, Dramaga Campus, Bogor 16680, Indonesia. \\ Email: irusmana@ipb.ac.id
}

Received 19 January 2015; Received in revised form 18 June 2015; Accepted 18 June 2015

\begin{abstract}
Aims: Particulate methane monooxygenase (pMMO) is an integral membrane protein that converts methane to methanol as the first step in the metabolic pathway of methanotroph bacteria. Methanotroph have a slow growth rate that make researcher have to develop an alternative approach by expressing the pMMO genes in Escherichia coli. However, it was very difficult to express all the pMMO encoded genes in $E$. coli and it is suspected that the protein might be toxic to $E$. coli. Therefore, this research tried another approach by expressing the active site of pMMO enzyme; cupredoxin domain of pmoB subunit encoded by $s p m o B$ gene.

Methodology and results: The spmoB gene from Methylococcus capsulatus (Bath) was expressed in E. coli BL21 (DE3) under T7 promoter and pET15b as the expression vector. Several modifications were made so this gene would be expressed in the cytoplasm. Expression analysis with SDS-PAGE showed that overexpression of this gene could be done at several concentrations of IPTG and incubation temperature. The $s p m o B$ gene expression produced a recombinant protein with a size approximately $38.9 \mathrm{kDa}$. Assay of spmoB protein activity showed that the amount of methanol accumulated during methane oxidation by the recombinant strain was $0.114 \mathrm{mmol} / \mathrm{mL}$ culture.h.

Conclusion, significance and impact study: We successfully expressed spmoB gene in E. coli BL21 (DE3) without high production of toxic compounds and it has methane oxidation activity. This result allowed further characterization of its potential applications.
\end{abstract}

Keywords: methanotroph, pMMO, spmoB, recombinant Escherichia coli

\section{INTRODUCTION}

Methanotroph are a group of bacteria that are able to grow by using methane as their source of carbon and energy (Hanson and Hanson, 1996). These bacteria have the metabolic oxidation pathway of methane to methanol which is catalyzed by methane monooxygenase (MMO) enzyme (Culpepper and Rosenzweig, 2012). The contribution of methane as a greenhouse gas is second only to carbon dioxide, and methane significantly absorbs more infrared radiation (Tol et al., 2003). Therefore, methanotroph with $\mathrm{MMO}$ has the potential to reduce methane emission in the atmosphere. However, the application of methanotroph is hindered by their relatively slow growth rate and low cell density (Gou et al., 2006).

MMO enzymes have been the focus of intense study recently for its ability to oxidize methane and other substrates, including halogenated hydrocarbons (Semrau et al., 2010). There are two types of MMO, a cytoplasmic complex; soluble methane monooxygenases (sMMO), and a membrane bound; particulate methane monooxygenases (pMMO). From all methanotroph that have been investigated, most produces $\mathrm{pMMO}$ and only some strains that have both sMMO and pMMO (Murrell et al., 2000). pMMO is the dominant enzyme in methane oxidation in nature, but this enzyme has proven to be difficult to isolate (Lieberman and Rosenzweig, 2004). Some studies were then performed to clone and express the pMMO genes in E. coli, but the product(s) of pMMO encoding gene clusters seem to be toxic (Murrell et al., 2000; Gou et al., 2006).

pMMO is encoded by pmoCAB operon where $p m o C$, $p m o A$, and $p m o B$ encode three pMMO polypeptide subunits respectively: $y$ subunit or pmoC $(22 \mathrm{kDa}), \beta$ or pmoA (24 kDa), and $\alpha$ or pmoB $(47 \mathrm{kDa})$ (Ngunyen et al., 1997; Lieberman and Rosenzweig, 2004). All three subunits form a complex trimeric structure $\alpha_{3} \beta_{3} \gamma_{3}$ (Lieberman and Rosenzweig, 2005; Hakemian et al., 2008; Smith et al., 2011a). Crystallography experiments on pMMO of Methylococcus capsulatus (Bath) showed 
that the active site allegedly contained in cupredoxin domain of pmoB subunit $(47 \mathrm{kDa})$ (Lieberman and Rosenzweig, 2005). pmoB subunit consists of the $\mathrm{N}$ terminal domain cupredoxin (spmoBd1) and C-terminal domain cupredoxin (spmoBd2) and is connected by two transmembrane helices. Both cupredoxin domain are in the periplasm and the only soluble domain (Culpepper and Rosenzweig, 2012). Initial 32 amino acid residues are thought to be a signal peptide (Semrau et al., 1995). Cupredoxin domain coding gene in pmoB subunit, $s p m o B$ gene, is thought to be the pMMO active site coding gene. The evidence has been shown by Smith et al. (2011b) which expressed only $s p m o B$ gene in $E$. coli and it still had methane oxidation activity.

In this study, we expressed gene from $M$. capsulatus (Bath) that encode pmoB subunit in E. coli BL21 (DE3). The transmembrane helices and signal peptides sequence of this gene have been eliminated. Methylococcus capsulatus (Bath) was chosen because the whole genome information, including pmoCAB operon, had been known (Ward et al., 2004). Structure and the active site information of pMMO had also been known (Lieberman and Rosenzweig, 2005; Smith et al., 2011b; Culpepper and Rosenzweig, 2012). This gene was expressed under control of T7 promoter and $\mathrm{pET} 15 \mathrm{~b}$ as the expression vector in E. coli BL21 (DE3).

\section{MATERIALS AND METHODS}

\section{Cloning of artificial spmoB gene}

Manufacture of artificial $s p m o B$ genes was done through corporate services with Integrated DNA Technologies, Inc. (IDT). Gene sequence of $s p m o B$ from $M$. capsulatus (Bath) was obtained from National Center for Biotechnology Information (NCBI) (http://www.ncbi.nlm.nih.gov/) website with the accession number of L40804.2. Then, artificial gene was amplified by polymerase chain reaction (PCR) (Gene Amp ${ }^{\circledR}$ PCR system 2720). Forward primer was spmoBd1F (5'GGAATTCCATATGCACGGTGAGAAATCGCGG-3') with Ndel enzyme recognition sites (underlined sequence) and spmoBd2R

CGGGATCCTTACATGAACGACGGGATCA-3') with

BamHI enzyme recognition sites (underlined sequence). The PCR reaction consisted of $5 \mathrm{U}$ of DNA polymerase (LA-Taq Takara), $1 \mathrm{ng}$ of artificial gene, $0.5 \mu \mathrm{M}$ of spmoBd1 primer, $0.5 \mu \mathrm{M}$ of spmoBd2R primer, $1 \times$ of buffer, and $0.25 \mu \mathrm{M}$ of dNTPs. Amplification was done in 12 cycles. The PCR condition used was pre-denaturation $\left(94^{\circ} \mathrm{C}, 30 \mathrm{sec}\right)$, denaturation $\left(94^{\circ} \mathrm{C}, 15 \mathrm{sec}\right)$, annealing (55 ${ }^{\circ} \mathrm{C}$, $\left.15 \mathrm{sec}\right)$, elongation $\left(72{ }^{\circ} \mathrm{C}, 30 \mathrm{sec}\right)$, and final elongation $\left(72^{\circ} \mathrm{C}, 5 \mathrm{~min}\right)$. The PCR products were purified and cloned into E. coli DH5a with the pGEM-T Easy vector (Promega, USA). Then, the coding region of $s p m o B$ was verified using DNA sequencing through corporate services with $1^{\text {st }}$ Base, Malaysia.

\section{Construction pET15b expression vector and transformation}

$s p m o B$ gene fragments were obtained by cutting the recombinant pGEM-spmoB plasmid with $\mathrm{Ndel}$ and $\mathrm{BamHI}$ restriction enzymes. The products were separated by $1 \%$ agarose gel and purified with Gel DNA Fragments Extraction Kit (Geneaid). pET15b plasmid which had also been digested with $\mathrm{Ndel}$ and $\mathrm{BamHI}$ was ligated with $s p m o B$ gene. Ligation process was done using T4 DNA ligase (Invitrogen, USA). Then recombinant plasmid pET15b-spmoB was transferred to $E$. coli BL21 (DE3) competent cells by heat shock treatment at temperature $42{ }^{\circ} \mathrm{C}$ for $60 \mathrm{sec}$. Transformants of E. coli BL21 (DE3) were screened using resistance of ampicillin. The bacteria were spread on the Luria agar (LA) media which contain ampicillin $100 \mu \mathrm{g} / \mathrm{mL}$. E. coli BL21 (DE3) colonies which carried recombinant plasmid were verified by colony PCR using spmoBd1F and spmoBd2R primers.

\section{Expression analysis of $s p m o B$ gene}

Escherichia coli BL21 (DE3) transformant were grown in 3 $\mathrm{mL}$ LB medium containing ampicilin $100 \mu \mathrm{g} / \mathrm{mL}$ for overnight at $37^{\circ} \mathrm{C}$. One hundred microliters of culture was used to inoculate $10 \mathrm{~mL}$ of LB and incubated at $27^{\circ} \mathrm{C}$ or $37^{\circ} \mathrm{C}$. When the optical density of the cells have reached $\mathrm{OD}_{600 \mathrm{~nm}}$ of 0.6. IPTG was added to the culture with several final concentration $(0.1 \mathrm{mM}, 0.5 \mathrm{mM}$, and $1.0 \mathrm{mM})$ and one culture was uninduced. All of the cultures were incubated for $4 \mathrm{~h}$ post induction. Up to $100 \mu \mathrm{L}$ of each culture was added into $30 \mathrm{~mL}$ sample buffer $(60 \mathrm{mM}$ Tris$\mathrm{HCl} \mathrm{pH} 6.8,25 \%$ glicerol, 14,4 mM $\beta$-mercaptoethanol, $0.1 \%$ bromophenol blue) and heated at $100{ }^{\circ} \mathrm{C}$ for $10 \mathrm{~min}$. Then each sample $(10 \mu \mathrm{L})$ was loaded into the well $12.5 \%$ polyacrylamide gel. Electrophoresis was performed at a fixed voltage of 80 volts, $50 \mathrm{~A}$ for $3 \mathrm{~h}$. Staining was done by Coomassie Brilliant Blue (CBB) for $30 \mathrm{~min}$ while destaining was by $10 \%$ acetic acid solution. Estimation size of the recombinant protein was calculated with value of relative mobility (Rf) and log molecular weight marker (BM). For comparison, the molecular weight of the spmoB recombinant protein was predicted based on the amino acid sequence through ExPASy software (http://web.expasy.org/compute pi).

\section{Assay of spmoB activity}

Escherichia coli BL21 (DE3) transformant were cultivated in $3 \mathrm{~mL}$ LB medium containing antibiotic ampicillin 100 $\mu \mathrm{g} / \mathrm{mL}$ for overnight at $27^{\circ} \mathrm{C}$. A total of $40 \mathrm{~mL}$ of the culture was used to inoculate $4 \mathrm{~mL}$ of LB medium containing antibiotic ampicillin $100 \mathrm{ug} / \mathrm{mL}$ and $10 \mu \mathrm{M}$ $\mathrm{CuSO}_{4}$ in a $12 \mathrm{~mL}$ tube. The cultures were incubated at $27{ }^{\circ} \mathrm{C}$ until the optical density of the cells have reached $\mathrm{OD}_{600 \mathrm{~nm}}$ of 0.6 . Then $0.1 \mathrm{mM}$ IPTG was added to the culture. The tube was closed with a rubber stopper, then the air in the head space was set so the composition was approximately $50 \%$ air and $50 \%$ methane. The culture were incubated at $27^{\circ} \mathrm{C}$ for $24 \mathrm{~h}$ post induction. A total of $1 \mathrm{~mL}$ culture was taken to be measured the amount of 
methanol accumulation by SNP reagent method (Zhan et al., 2010).

\section{RESULTS}

\section{Cloning of artificial spmoB gene}

Amplification of $s p m o B$ artificial gene with spmoBd1 $\mathrm{F}$ and spmoBd2R primer produced $\pm 900 \mathrm{bp}$ amplicon (Figure 1). This gene was successful to be cloned into E. coli DH5 $a$ with the pGEM-T Easy vector (Promega, USA).

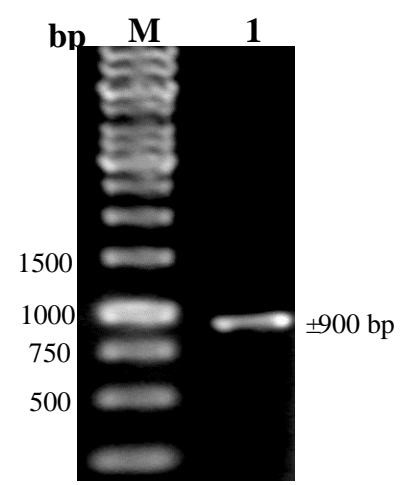

Figure 1: Visualization of $s p m o B$ amplicon in $1 \%$ agarose gel (w/v). M, marker $1 \mathrm{~kb}$; 1 , amplicon of $s p m o B$ artificial gene with the size $\pm 900 \mathrm{bp}$.

\section{Construction pET15b expression vector and transformation}

$s p m o B$ artificial gene was designed to encode the pMMO spmoBd1 (amino acid residues 34-172) and spmoBd2 (amino acid residues 265-415) domains that were connected by 6 amino acids (Gly-Gly-Lys-Leu-Gly-GlyGly) (Figure 2). Recognition site of Ndel acts as replacement of start codon.

\section{Expression analysis of $s p m o B$ gene and assay of spmoB activity}

Overexpression of $s p m o B$ occured either at $27^{\circ} \mathrm{C}$ or at 37 ${ }^{\circ} \mathrm{C}$. IPTG with final concentration of $0.1 \mathrm{mM}, 0.5 \mathrm{mM}$, and $1.0 \mathrm{mM}$ could also induce $s p m o B$ gene expression (Figure 3). Molecular weight of spmoB was predicted to be $32.9 \mathrm{kDa}$ by Expasy (Figure 4). Based on the calculation of relative mobility, spmoB recombinant protein was estimated to be $38.97 \mathrm{kDa}$. After $24 \mathrm{~h}$ IPTG induction, the amount of methanol in the culture was $2.736 \mathrm{mmol} / \mathrm{mL}$. For the E. coli BL21 (DE3) non transformant, no product was found during the detection of spmoB activity.

\section{DISCUSSION}

Gene size of pmoB subunit in $M$. capsulatus (Bath) is 1245 bp. This gene consists of 96 bp peptide signal encoder (residues 1-32), 420 bp spmoBd1 encoder (residues 33-172), 279 bp two transmembrane helices encoder (residues 173-264), and 450 bp spmoBd2 encoder (residues 265-414). Then, modifications were made: removal of the signal peptide sequence and replacement of the two transmembrane helices sequence with 6 amino acids. Elimination of the $96 \mathrm{bp}$ of peptide signal and $279 \mathrm{bp}$ of two transmembrane helices sequences aimed to express $s p m o B$ in the cytoplasm, since there were many cases of membrane protein expression resulted toxicity in E. coli (Miroux and Walker, 1996). Elimination of $96 \mathrm{bp}$ first sequence caused the disappearance of start codon. This start codon was replaced by Ndel recognition site that had ATG sequence so the translation could still be taken place. Transmembrane helices were also eliminated. Until now, the function of the transmembrane regions has not been elucidated (Culpepper and Rosenzweig, 2012). Amino acids Gly-Lys-Leu-Gly-Gly-Gly linker was used to replace the two transmembrane helices to connect residue 172 and 265. The glycine residues were selected because it could impart flexibility of the enzyme (Balasubramanian et al., 2010). The pmoB gene, that was originally sized 1245 $\mathrm{bp}$, shortened into $891 \mathrm{bp}$. Addition of some bases was the recognition sequences of $\mathrm{Ndel}$ and $\mathrm{BamHI}$.

We expressed the $s p m o B$ gene in E. coli BL21 (DE3). The advantages of using $E$. coli as the host organism are well known. It has unparalleled kinetics of fast growth, high cell density cultures are easily achieved, complex rich media can be made from readily available and inexpensive components, and transformation with exogenous DNA is fast and easy (Rosano and Ceccarelli, 2014). Then, compared to the relatively slow growth of $M$. capsulatus (Bath), the theoretical density limit of an E. coli culture liquid is estimated to be about $200 \mathrm{~g}$ cells/L (Lee, 1996; Shiloach and Fass, 2005).

Overexpression of $s p m o B$ gene in E. coli BL21 (DE3) with IPTG induction was successfully done. Several variants of IPTG final concentration and temperature of incubation were used to determine the effect on the expression. In this study, recombinant $E$. coli was able to express spmoB recombinant protein both at $27^{\circ} \mathrm{C}$ and 37 ${ }^{\circ} \mathrm{C}$. The effect of different final concentrations of IPTG on $s p m o B$ expression was examined and the result showed that $0.1 \mathrm{mM}, 0.5 \mathrm{mM}$, and $1.0 \mathrm{mM}$ IPTG could induce well the expression of recombinant gene. In several cases, incubation temperature greatly affects the expression of recombinant proteins in $E$. coli and the concentration of IPTG also can influence expression dramatically (Khlebnikov and Keasling, 2002; Gopal and Kumar, 2013). In this case, IPTG $0.1 \mathrm{mM}$ could induce the expression as well as IPTG $0.5 \mathrm{mM}$ and $1.0 \mathrm{mM}$. This result showed that IPTG $0.1 \mathrm{mM}$ could bind almost all of the lac repressor. The enhancement of IPTG concentration would not give the difference of expression level anymore if all of the lac repressor has been binded.

Expression of $s p m o B$ gene produced a recombinant protein with a size approximately $38.9 \mathrm{kDa}$ and it was different from ExPASy prediction. This difference was due to the addition of six histidine residues and some amino acids at upstream of the protein. The size of recombinant protein became smaller than the size of the pmoB subunit 


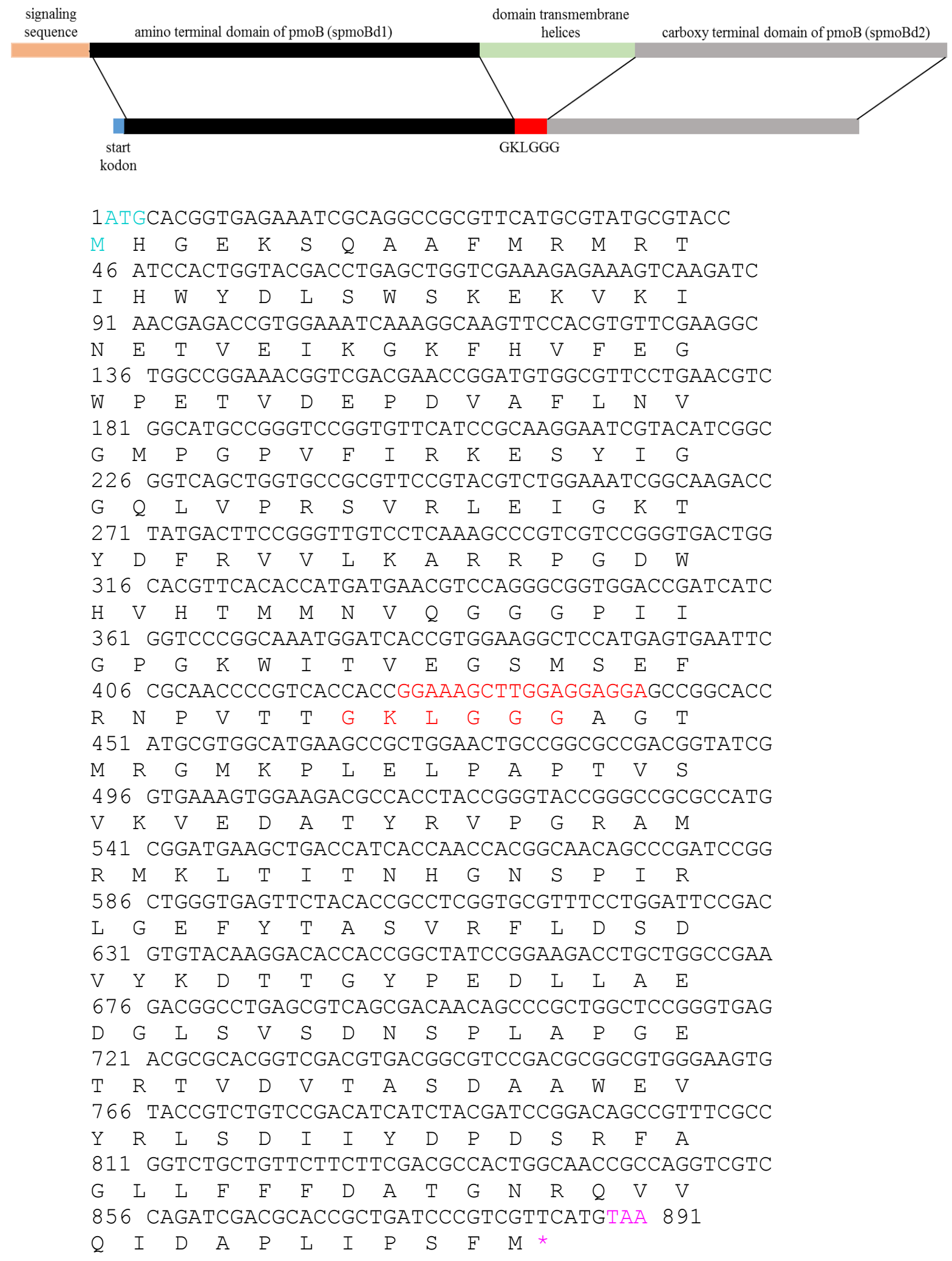

Figure 2: Illustration of artificial gene design and spmoB gene sequence from $M$. capsulatus (Bath) that was used. 


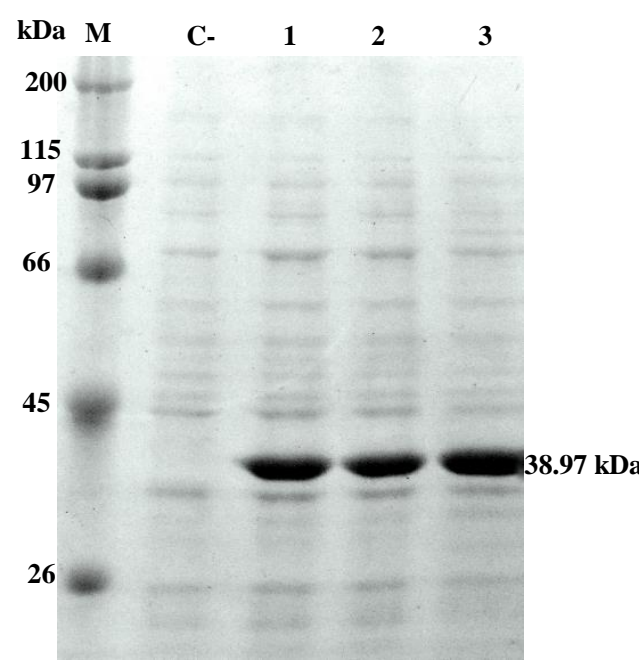

A

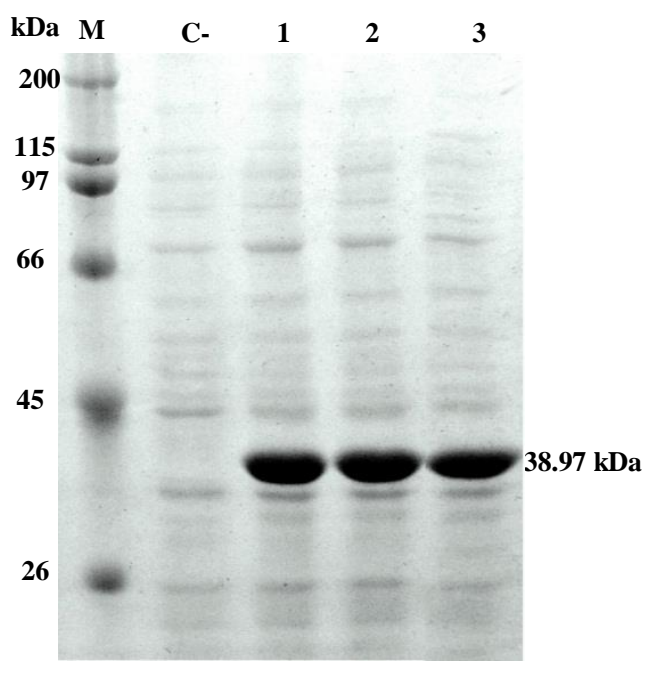

B

Figure 3: Analysis of $s p m o B$ gene expression by SDS-PAGE was resulting a recombinant protein with the size 38.97 $\mathrm{kDa}$. A, incubation at $27^{\circ} \mathrm{C}$; $\mathrm{B}$, incubation at $37^{\circ} \mathrm{C}$. M, Marker protein; C-, bacterial transformant was uninduced by IPTG; 1 , induction of 0.1 mM IPTG; 2 , induction of 0.5 mM IPTG; 3, induction of $1.0 \mathrm{mM}$ IPTG.

\begin{tabular}{|c|c|c|c|c|c|}
\hline $1 \underline{0}$ & 20 & 30 & 40 & 50 & 60 \\
\hline $\mathrm{HGEKSQAA \overline {F }}$ & MRMRT I HWY $\bar{D}$ & LSWSKEKVKI & NETVEIKGK $\bar{F}$ & HVFEGWPETV & DEPDVAFLNV \\
\hline 70 & 80 & 90 & 100 & 110 & 20 \\
\hline GMPGPVFIR $\bar{K}$ & ESYIGGQLVP & RSVRLEIGKT & YDFRVVLKA $\bar{R}$ & RPGDWHVHTM & MNVQGGGPI \\
\hline $13 \underline{0}$ & 140 & $15 \underline{0}$ & 160 & $17 \underline{0}$ & 18 \\
\hline PGKWITVE $\bar{G}$ & SMSEFRNPVT & TGKLGGGAGT & MRGMKPLEL $\bar{P}$ & APTVSVKVE $\bar{D}$ & ATYRVPGRAI \\
\hline $19 \underline{0}$ & $20 \underline{0}$ & 210 & 220 & 230 & 240 \\
\hline MKLTITNHG & NSPIRLGEFY & TASVRFLDSD & VYKDTTGYPE & DLLAEDGLSV & SDNSPLAPGE \\
\hline $25 \underline{0}$ & 260 & $27 \underline{0}$ & 280 & 290 & \\
\hline
\end{tabular}

Theoretical pl/Mw: $6.11 / 32.93462$

Figure 4: Isoelectric point $(\mathrm{pl})$ and molecular weight measurement $(\mathrm{Mw})$ prediction of spmoB recombinant protein by Expasy software.

(47 kDa) because of the transmembrane helices domain removal. This protein size is same as the size of spmoB recombinant protein reported by Balasubramanian et al. (2010).

The spmoB activity in E. coli BL21 (DE3) transformant was also assayed. Bacterial cells cultivated after $24 \mathrm{~h}$ IPTG induction in LB medium were used. The activity of the recombinant strain was $0.114 \mathrm{mmol} / \mathrm{mL}$ culture.h. For the E. coli BL21 (DE3) non transformant, no product was found during the detection of spmoB activity. This control experiment confirmed that the observed monooxygenase activity in the recombinant $E$. coli BL21 (DE3) was due to the cloned enzyme. The spmoB activity has not been optimal yet. This was presumably due to the strong promoter of T7 used in this study. In high level expression, rapid intracellular protein accumulation and expression of large proteins increase the probability of aggregation and leads to protein instability (Jonasson et al., 2002; Palomares et al., 2004). These buildups of protein aggregates are known as inclusion bodies.

In the end, our research succeeded to express recombinant protein $\mathrm{spmoB}$ in large quantity and it has methane oxidation activity. However, inclusion bodies was formed so purify and in vitro refolding steps have to be performed. The ability to express and purify the desired recombinant proteins in a large quantity allows for its biochemical characterization and the development of commercial goods.

\section{ACKNOWLEDGEMENTS}

This study was supported by Directorate General of Higher Education, Ministry of National Education, Republic of Indonesia. 


\section{REFERENCES}

Balasubramanian, R., Smith, S. M., Rawat, S., Yatsunyk, L. A., Stemmler, T. L. and Rosenzweig, A. C. (2010). Oxidation of methane by a biological dicopper. Nature 465, 115-121.

Culpepper, M. A. and Rosenzweig, A. C. (2012). Architecture and active site of particulate methane monooxygenase. Critical Reviews in Biochemistry and Molecular Biology 47, 483-492.

Gopal, G. J. and Kumar, A. (2013). Strategies for the production of recombinant protein in Escherichia coli. Protein Journal 32, 419-425.

Gou, Z., Xing, X. H., Luo, M., Jiang, H., Han, B., Wu, H., Wang, L. and Zhang, F. (2006). Functional expression of the particulate methane monooxygenase gene in recombinant Rhodococcus erythropolis. Federation of European Microbiological Societies Microbiology 263, 136-141.

Hakemian, A. S., Kondapalli, K. C., Telser, J., Hoffman, B. M., Stemmler, T. L. and Rosenzweig, A. C. (2008). The metal centers of particulate methane monooxygenase from Methylosinus trichosporium OB3b. Biochemistry 47, 6793-6801.

Hanson, R. S. and Hanson, T. E. (1996). Methanotrophic bacteria. Microbiology Review 60, 439-471.

Jonasson, P., Liljeqvist, S., Nygren, P. A. and Stahl, S. (2002). Genetic design for facilitated production and recovery of recombinant proteins in Escherichia coli. Biotechnology Applied Biochemistry 35, 91-105.

Khlebnikov, A. and Keasling, J. D. (2002). Effect of lacY expression on homogeneity of induction from the $\mathrm{P}(\mathrm{tac})$ and $\mathrm{P}(\operatorname{trc})$ promoters by natural and synthetic inducers. Biotechnology Progress 18, 672-674.

Lee, S. Y. (1996). High cell-density culture of Escherichia coli. Trends in Biotechnology 14, 98-105.

Lieberman, R. L. and Rosenzweig, A. C. (2004). Biological methane oxidation: Regulation, biochemistry, and active site structure of particulare methane monooxygenase. Critical Review in Biochemical and Molecular Biology 39, 149-164.

Lieberman, R. L. and Rosenzweig, A. C. (2005). Crystal structure of membrane-bound mettaloenzyme that catalyses the biological oxidation of methane. Nature 434, 177-182.

Miroux, B. and Walker, J. E. (1996). Over-production of protein in Escherichia coli: Mutant host that allow synthesis of some membrane proteins and globular proteins at high levels. Journal of Molecular Biology 260, 289-298.

Murrell, J. C., Gilbert, B. and McDonald, I. R. (2000). Molecular biology and regulation of methane monooxygenase. Archives of Microbiology 173, 325332.

Ngunyen, H. H., Ellieott, S. J., Yip, J. H. K. and Chan, S. I. (1997). The particulate methane monooxygenase from Methylococcus capsulatus (Bath) is a novel copper-containing three-subunit enzyme. The Journal of Biological Chemistry 273, 7957-7966.
Palomares, L. A., Mondaca, S. E. and Raminez, O. T. (2004). Production of recombinant proteins, challenges and solutions. Methods in Molecular Biology 267, 1551.

Rosano, G. L. and Ceccarelli, E. A. (2014). Recombinant protein expression in Escherichia coli: advance and challenges. Frontiers in Microbiology 5, 1-17.

Semrau, J. D., Chistoserdov, A., Lebron, J., Costello, A., Davagnino, J., Kenna, J. E., Holmes, A. J., Finch, R. and Murrell, J. C. (1995). Particulate methane monooxygenase genes in methanotrophs. Journal of Bacteriology 177, 3071-3079.

Semrau, J. D., Dispirito, A. A. and Yoon, S. (2010). Methanotrophs and copper. Federation of European Microbiological Review 34, 496-531.

Shiloach, J. and Fass, R. (2005). Growing E. coli to high cell density - a historical perspective on method development. Biotechnology Advances 23, 345-357.

Smith, S. M., Rawat, S., Telser, J., Hoffman, B. M., Stemmler, T. L. and Rosenzweig, A. C. (2011a). Chrystal structure and characterization of particulate methane monooxygenase from Methylocystis species strain M. Biochemistry 50, 10231-10240.

Smith, S. M., Balasubramanian, R. and Rosenzweig, A. C. (2011b). Metal reconstitution of particulate methane monooxygenase and heterologous expression of the pmoB subunit. Methods in Enzymology 495, 195-210.

Tol, R. S. J., Heintz, R. J. and Lammers, P. E. M. (2003). Methane emission reduction: An application of FUND. Climatic Change 57, 71-98.

Ward, N., Larsen, O., Sakwa, J., Bruseth, L., Khouri, H., Durkin, S., Dimitrov, G., Jiang, L., Scanlan, D., Kang, K. H., Lewis, M., Nelson, K. E., Methe, B., Wu, M., Heidelberg, J. F., Paulsen, I. T., Fouts, D., Ravel, J., Tettelin, H., Ren, Q., Read, T., DeBoy, R. T., Seshadri, R., Salzberg, S. L., Jensen, H. B., Birkeland, N. K., Nelson, W. C., Dodson, R. J., Grindhaug, S. H., Holt, I., Eidhammer, I., Jonase, I., Vanaken, S., Utterback, T., Feldblyum, T. V., Fraser, C. M., Lillehaug, J. R. and Eisen, J. A. (2004). Genomic insights into methanotrophy: The complete genome sequence of Methylococcus capsulatus (Bath). Plos Biology 2, 1616-1628.

Zhan, Y. Y., Zhang, Y., Li, Q. M. and Du, X. Z. (2010). A novel visible spectrophotometric method for the determination of methanol using sodium nitroprusside as spectroscopic probe. Journal of the Chinese Chemical Society 57, 230-235. 